\title{
Adrenarche: Postnatal Adrenal Zonation and Hormonal and Metabolic Regulation
}

\author{
Alicia Belgorosky María Sonia Baquedano Gabriela Guercio Marco A. Rivarola \\ Servicio de Endocrinología, Hospital de Pediatría Garrahan, Buenos Aires, Argentina
}

\section{Key Words}

Adrenarche, premature $\cdot$ Adrenal cortex-medulla interaction - GH-IGF system • Adrenal androgens • Estrogen receptor

\begin{abstract}
Adrenarche is the direct consequence of the organogenesis of the zona reticularis (ZR). Proliferation of cortical cells could take place in the outermost layers of the adrenal cortex. Cells could then migrate to differentiate the zona glomerulosa (ZG) and zona fasciculata (ZF) during fetal life, and the ZR during postnatal life. After adrenarche, there are detectable increases in circulating DHEA and DHEA-S. Adrenarche could result from an increase in 17,20-lyase activity of $\mathrm{P} 450 \mathrm{c} 17 \mathrm{sec}-$ ondary to high levels of cytochrome $b_{5}$ expression, and from a decrease in $3 \beta H S D 2$ expression along with an increase in the expression of SULT2A1 in the ZR. The GH-IGF system and insulin, among other factors, might also modulate adrenal androgen production. Furthermore, high concentrations of estradiol enhance basal and ACTH-stimulated DHEA-S production, while aromatase expression was observed in the human adrenal medulla but not in the ZR, suggesting that estrogens produced in the adrenal medulla might be involved in the regulation of androgen production in the ZR. Premature adrenarche might be associated with ovarian hyperandrogenism and polycystic ovarian syndrome in females, as well as with insulin resistance in both sexes. However, many questions remain, transforming adrenal androgens into markers of diseases important for human health.
\end{abstract}

Copyright $\odot 2008$ S. Karger AG, Basel

\section{Introduction}

Adrenarche occurs only in higher primates, typically at 6-8 years of age in humans, when the innermost layer of adrenal cortex, the zona reticularis (ZR), develops. This is an event of postnatal sexual maturation in which there is an increase in the secretion of adrenal androgens, mainly dehydroepiandrosterone (DHEA) and dehydroepiandrosterone sulfate (DHEA-S), not accompanied by an increase in cortisol secretion [1]. The ZR is in theory the morphological equivalent to the fetal zone of the adrenal cortex. The primate adrenal produces large a mounts of DHEA and DHEA-S during fetal development, which decrease rapidly after birth, since the fetal zone virtually disappears during the first few months of postnatal life [2]. Thereafter, longitudinal studies have shown a progressive increase in serum concentrations of DHEA and DHEA-S in healthy boys and girls, beginning at 6-8 years of age, roughly in parallel with an increase in skeletal age $[3,4]$. However, in contrast to the latter proposal, adrenarche might begin earlier in childhood, as suggested by studies performed in healthy children measuring DHEA, as well as the DHEA metabolites in 24-hour urine samples [5].

Even though adrenarche might be a multifactorial event, the main process regulating the production of adrenal androgens continues to represent one of the most intriguing mysteries in adrenal functional differentiation.

\begin{tabular}{ll}
\hline KARGER & ( 2008 S. Karger AG, Basel \\
0301-0163/08/0705-0257\$24.50/0 \\
$\begin{array}{l}\text { Fax +4161306 1234 } \\
\begin{array}{l}\text { E-Mail karger@karger.ch } \\
\text { www.karger.com }\end{array}\end{array}$ & $\begin{array}{l}\text { Accessible online at: } \\
\text { www.karger.com/hre }\end{array}$
\end{tabular}

Alicia Belgorosky

Servicio de Endocrinolología, Hospital de Pediatría Garrahan

C. de los Pozos 1881

Buenos Aires 1245 (Argentina)

Tel. +54 114308 0034, Fax +54 114308 5325, E-Mail abelgo@elsitio.net 


\section{Development and Functional Zonation of the Human Adrenal Gland}

Regulators of Adrenal Androgen Production:

Implications for Adrenarche

The developmental program that gives rise to the adrenal gland begins early during embryogenesis and continues into adult life. There are undeniable species-specific differences in the structural and functional organization of the human and great primate adrenal cortex compared to non-primate species [6].

\section{Differentiation and Function of the Fetal Adrenal Cortex}

The fetal adrenal cortex derives from a common adrenogonadal precursor lineage that also gives raise to the steroid-secreting cells of the gonads. In human embryos, these adrenogonadal progenitors first appear in the 4 th week of gestation. Cells destined to generate the adrenal cortex migrate from the celomic epithelium forming the primitive adrenal gland by 8 weeks of gestation. This rudimentary adrenal gland contains an inner cluster of large, eosinophil cells, termed the fetal zone. Shortly thereafter, a second group of cells develops to form a densely packed outer zone of cells, the definitive zone. At the same time, the adrenal cortex becomes encapsulated and chromaffin cells originating from the neural crest migrate through the fetal cortex to progressively colonize the center of the gland to form the future adrenal medulla $[6,7]$. However, it is not until 12-18 months of age that the adrenal medulla becomes adult-like in appearance.

Genes encoding a number of transcription factors have been linked to adrenocortical cell development and to modulation of steroidogenic function $[7,8]$. The large inner fetal zone expressing the cholesterol sidechain cleavage enzyme (CYP11A) and $17 \alpha$-hydroxylase (CYP17), but not 3 $\beta$-hydroxysteroid dehydrogenase (HSD3B2), is the site of synthesis of large amounts of DHEA and DHEA-S from early in development [9]. Definitive zone cells have a proliferation phenotype that persists throughout gestation, and they acquire mineralocorticoid synthesis capacity only late in gestation. A third zone, the transition zone, develops between the definitive and fetal zone around mid-gestation, and it expresses enzymes required for the synthesis of cortisol [9].

\section{Remodeling of the Postnatal Adrenal Cortex and} Development of Zona Reticularis

After birth, a strong remodeling of the adrenal gland occurs; the medulla islands coalesce to form a rudimentary medulla, the fetal zone regresses by the 3rd postnatal month, primarily by apoptosis $[2,10]$, and the definitive and transition zones develop into the adult adrenal. These morphologic changes are accompanied by a rapid drop in DHEA and DHEA-S production due to the involution of the fetal zone. In pre-adrenarche children, the zona glomerulosa $(Z G)$ and the zona fasciculata (ZF) are clearly present but only focal islands of ZR cells, insufficient to influence serum DHEA-S levels, can be identified at the ages 3-5 years [11-13]. After adrenarche, a continuous layer of reticularis cells develops and thickens forming the ZR. This process is associated with detectable increases in circulating DHEA and DHEA-S $[3,4]$.

The origin of the adrenocortical zones and the regulation of their proliferation are incompletely understood. At present the progenitor cell proliferation/migration theory is the most accepted one [14]. It proposes that proliferation of cortical cells takes place in the outermost layers of the adrenal cortex. The theory could be valid for the differentiation of the ZG and ZF during fetal life, as well as for the ZR during postnatal life. Hence, all cells of the adrenal cortex could have a common origin which becomes functionally differentiated in the appropriate zone environment (fig. 1).

Although the accumulated data point strongly to the progenitor cell proliferation/migration theory in adrenal gland differentiation, the evidence is not direct. On the other hand, there are few data concerning the mechanisms responsible for the apparent shrinkage of the ZR with aging.

\section{Functional Specialization of the Adult Adrenal}

Cortex Zones: Adrenal $\Delta^{5}$-Androgens Are Synthesized in the $Z R$

In the adult adrenal, the three steroidogenically and morphologically distinct zones of the cortex, ZG, ZF and $\mathrm{ZR}$ are responsible for the production of aldosterone, cortisol, and DHEA/DHEA-S, respectively. Although some enzymes and cofactor proteins are common to all adrenal cortex zones, the specific classes of steroids produced are determined predominantly by zone-specific expression of characteristic steroidogenic enzymes for each zone. The expression of P450c17 in the ZR along with low levels of $3 \beta-H S D$ expression, leads to the synthesis of DHEA and DHEA-S [15]. 


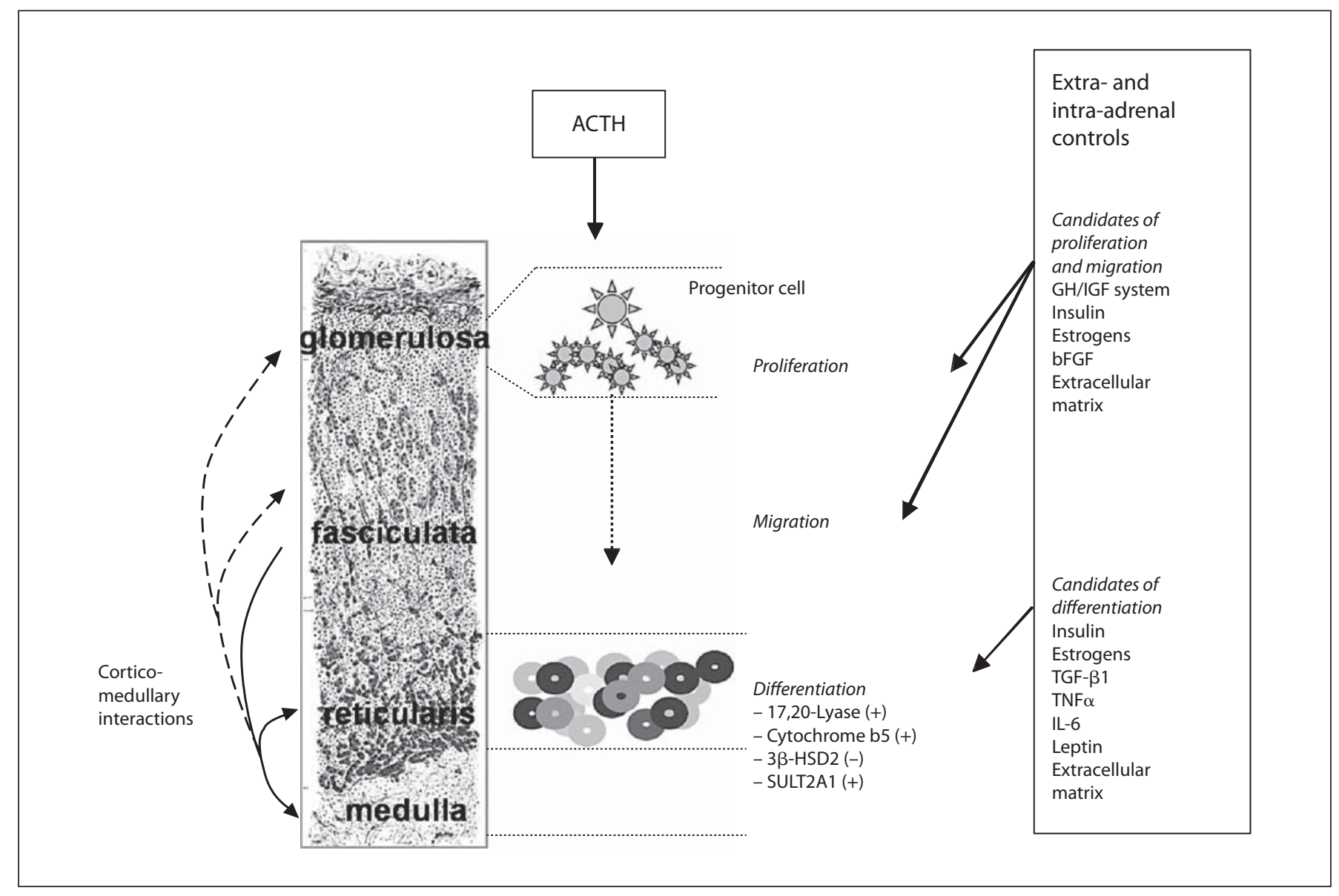

Fig. 1. Growth and differentiation (zonation) of the adult adrenal gland. The scheme depicts the progenitor cell differentiation/migration and its putative regulation for ZR formation. Under the permissive action of ACTH, directly essential for proliferation and cortisol secretion in the ZF, and indirectly for adrenal medulla function, progenitor cell proliferation in the periphery, as well as subsequent migration toward the center of the gland, might be stimulated by several factors, as shown. Upon arrival in the ZR area, other factors might stimulate (and inhibit) transcription of specific genes necessary for the differentiated function of ZR cells. In turn, factors secreted by the adrenal medulla might contribute to adrenal cortex zonation, particularly in ZR [60]. Copyright 2007, Humana Press-Springer.
The conversion of pregnenolone to DHEA requires only the P450c17 enzyme. CYP17 is the gene encoding this single microsomal enzyme responsible for the metabolism of pregnenolone to $17 \alpha$-hydroxypregnenolone (17 $\alpha$-hydroxylase activity) and $17 \alpha$-hydroxypregnenolone to DHEA (17,20-lyase activity) [16]. That is, while only $17 \alpha$-hydroxylase activity is necessary for glucocorticoid synthesis, $17 \alpha$-hydroxylase and 17,20-lyase activities of $\mathrm{P} 450 \mathrm{cl} 17$ are necessary for androgen production. 17,20-Lyase activity increases at adrenarche, while cortisol production does not change appreciably. Thus, it has been suggested that a specific induction of 17,20-lyase activity of CYP17 is responsible for the greater $\mathrm{C}_{19}$ steroid production by ZR as adrenarche progresses [17]. The ratio of 17,20 -lyase to $17 \alpha$-hydroxylase activity of $\mathrm{P} 450 \mathrm{c} 17$ is regulated post-translationally by at least three factors: the abundance of the electron-donating protein P450 oxidoreductase, the presence of cytochrome b5 [11], and the serine phosphorylation of P450c17; all of which could be influenced at adrenarche [17].

Another key regulatory process in DHEA biosynthesis is the impairment of the flux of steroids from the $\Delta^{5}$ pathway to the $\Delta^{4}$ pathway. Enzymes such as $3 \beta$-HSD and $21-$ hydroxylase, also termed P450c21 (CYP21), normally act to decrease DHEA production through competition with $\mathrm{P} 450 \mathrm{cl} 7$ in the case of $3 \beta-\mathrm{HSD}$, and through the removal of steroid precursors in the case of $\mathrm{P} 450 \mathrm{c} 21$. 
In humans, two $3 \beta-H S D$ are expressed: type $13 \beta-$ HSD is found in the liver, skin, placenta and other peripheral tissues, and type $23 \beta$-HSD (3 $\beta$-HSD2), expressed in adrenal and gonads [18], is essential for aldosterone and cortisol production in the ZG and ZF. On the contrary, $3 \beta$-HSD2 expression in the ZR would drain steroid flux away from the $\Delta^{5}$ pathway leading to DHEA, and it would produce androstenedione instead. Reverse transcriptasepolymerase chain reaction experiments show that adrenarche is associated with a decline in 3 $\beta-H S D 2$ expression [19], and immunohistochemistry studies localize this deficiency to the ZR $[11,12]$. However, the mechanisms regulating the poor or absent expression of $3 \beta$ HSD2 in ZR cells have not been defined, as yet. Recent studies suggest that $3 \beta-\mathrm{HSD} 2$ transcription is regulated in part by NGFI-B (nur77 or NR4A1), a member of the NGFI-B family of orphan nuclear receptors (nerve growth factor-induced clone B) [20]. Moreover, it has been confirmed that within the adult and fetal adrenal gland, NGFI-B expression parallels the expression of HSD3B2 $[20,21]$. On the other hand, the expression of NGFI-B was inversely correlated with the ability of the tissues to produce DHEA [20]. This inverse correlation between adrenal androgen production and the expression of NGFI-B and HSD3B2 appears to be a unifying link for the production of DHEA by the fetal and adult adrenal reticularis.

It is worth mentioning that most of DHEA synthesized by the fetal adrenal cortex and the ZR of the adult adrenal is sulfated by the DHEA-sulfotransferase enzyme (SULT2A1) and secreted as DHEA-S. Expression of SULT2A1 remains low through early childhood, increases after adrenarche in the $\mathrm{ZR}$, and continues into adulthood [11].

Consequently, adrenarche could result from an increase in the 17,20-lyase activity of P450c17 secondary to high levels of cytochrome $b_{5}$ expression, as well as from a decrease in $3 \beta H S D 2$ expression along with an increase in the expression of SULT2A1, in the adrenal ZR. This particular phenotype maximizes DHEA-S production by these cells. It is clear that the regulation of adrenarche is a complex event with multiple levels of regulation of adrenal steroidogenesis.

The pituitary hormone ACTH is the primary regulator of both fetal adrenal development and adult adrenal cortex homeostasis and steroidogenic function. However several experiments and clinical observations have shown that ACTH is necessary but not sufficient to induce adrenarche [22-24] suggesting that other factors must be involved in the specific regulation of DHEA and DHEA-S synthesis in the adrenal gland. These factors have to be

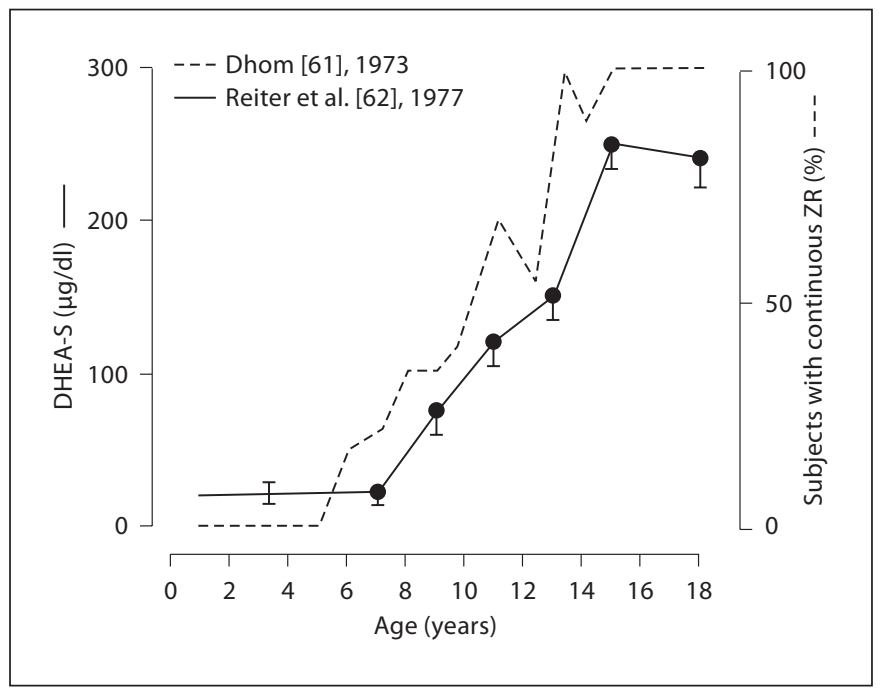

Fig. 2. Change in serum DHEA-S with age related to growth of the zona reticularis. Relation of plasma DHEA-S to growth of the ZR and increase in adrenal volume [4]. Copyright 2000, The Endocrine Society.

involved either in the regulation of adrenal enzyme expression and action or in the growth and trophic maintenance of the ZR itself (fig. 2).

Peak levels of DHEA and DHEA-S occur at age 20-25 years and decline thereafter [13]. This decrease in adrenal androgens with aging is often called adrenopause. There appears to be a reduction in the width of the ZR with aging, without overall changes in the width of the adrenal cortex. This suggests that this phenomenon is specific to the ZR, and not global atrophy of the adrenal gland with aging [13].

The GH-IGF System and Insulin: Possible Modulators of Adrenal Androgens

There is some evidence that the GH-IGF system and insulin might be regulating factors of adrenal androgen production at adrenarche. Some evidence points to an important role for IGF-II in the regulation of FZ development. In addition, both IGF-I and IGF-II enhance steroidogenic enzyme activity of P450c17 and 3 $\beta$-HSD [25]. However, studies of IGF-I, IGF-II and IGF-R1 mRNA expression and immunolocalization in human adrenals, from early infancy to late puberty, show very low IGF-RI expression in the ZR, suggesting that the IGF system is not directly involved in the regulation of adrenal androgen via ZR cells. Therefore, it has been proposed that IGFI and perhaps IGF-II are involved at another level, either 


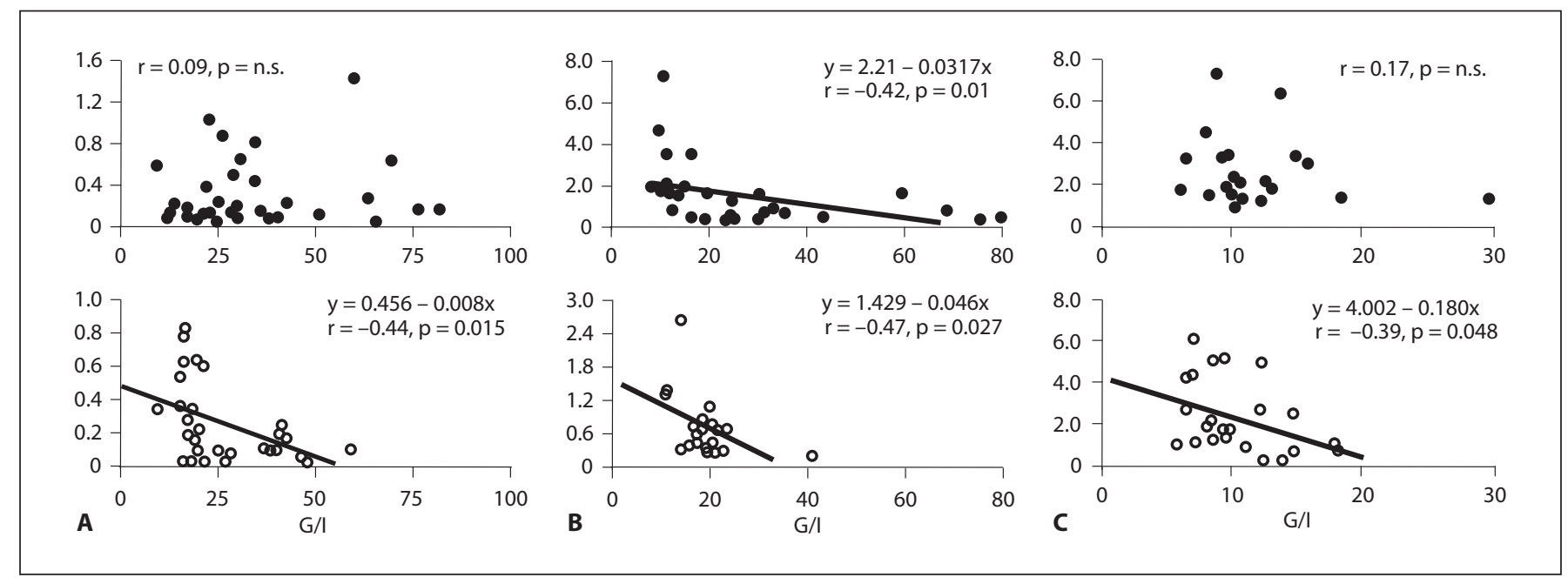

Fig. 3. Relationship between serum DHEA-S and insulin sensitivity (G/I), estimated by the serum fasting glucose/serum insulin ratio, in milligrams per $10^{-4} \mathrm{U}$ : prepuberty $(\mathbf{A})$; transition from late prepuberty to early puberty $(\mathbf{B})$, and puberty $(\mathbf{C}) . \bullet=$ Boys; $\bigcirc$ = girls.

by autocrine, paracrine or endocrine stimulation, in the postnatal mechanisms of progenitor adrenal cell proliferation and migration [26]. Although circulating and tissue IGF-II levels are highest during fetal life and decrease postnatally, a postnatal role of IGF-II in the adrenal gland cannot be discarded. In addition, serum IGF-I levels rise and fall in a pattern similar to serum DHEA-S, and normal puberty is characterized by a state of transient insulin resistance associated with an increase in not only gonadal sex steroid production but also adrenal androgens. Therefore, a role has been proposed for the GH/IGF system and insulin on the developmental changes taking place at adrenarche [27-29]. The GH/IGF system and adiposity have been considered the major contributors of insulin resistance at puberty [27-33]. Several studies have shown pubertal female-male differences in insulin sensitivity, normal girls being less insulin-sensitive than normal boys [28, 34-37]. However, it was found that these sex differences were clearly evident in late prepuberty, when girls become more insulin-resistant than boys [36, 37], and a similar finding was described by Hoffman et al. [34] in a small sample of subjects. In contrast, Denburg et al. [38] found a significant correlation between serum DHEA-S and IGF-I in 8 normal boys, but not in boys with premature adrenarche. In vivo studies of the implications of insulin-resistance and the GH/IGF system on the regulation of adrenal androgen secretion are scarce in normal children at adrenarche. Bloch et al. [39] found that healthy children at adrenarche were more insulin-resis- tant than younger ones, and an inverse relationship between insulin sensitivity and DHEA-S levels was also found. On the contrary, no relationship between DHEA$S$ levels and insulin sensitivity was observed in normal prepubertal and adolescent subjects of both sexes by Caprio et al. [40]. Finally, while Smith et al. [41] described a positive correlation between DHEA-S levels and basal or stimulated insulin responses when prepubertal and pubertal children were analyzed together, they were unable to detect a significant correlation in the prepubertal group alone. In addition, a sexual dimorphism was described by Guercio et al. [35, 37]. Contrarily to this finding in boys, Guercio et al. [37] reported a significant decrease in insulin sensitivity as well as a significant negative correlation between serum DHEA-S levels and insulin sensitivity in normal prepubertal girls, and also during pubertal development (fig. 3), suggesting that the GH/IGF axis and insulin sensitivity might be important metabolic signals involved in the maturational changes of the human adrenal at the time of adrenarche.

Other local factors such as cytokines produced by the inner zones of the human adrenal cortex could participate in the differentiation and apoptosis of the ZR [42].

\section{Local Estrogen Synthesis and Action: Another}

Participant in Adrenal Androgen Modulation?

A potential role for steroids, particularly estradiol, in promoting adrenal androgen production has been suggested. High concentrations of estradiol enhance basal 


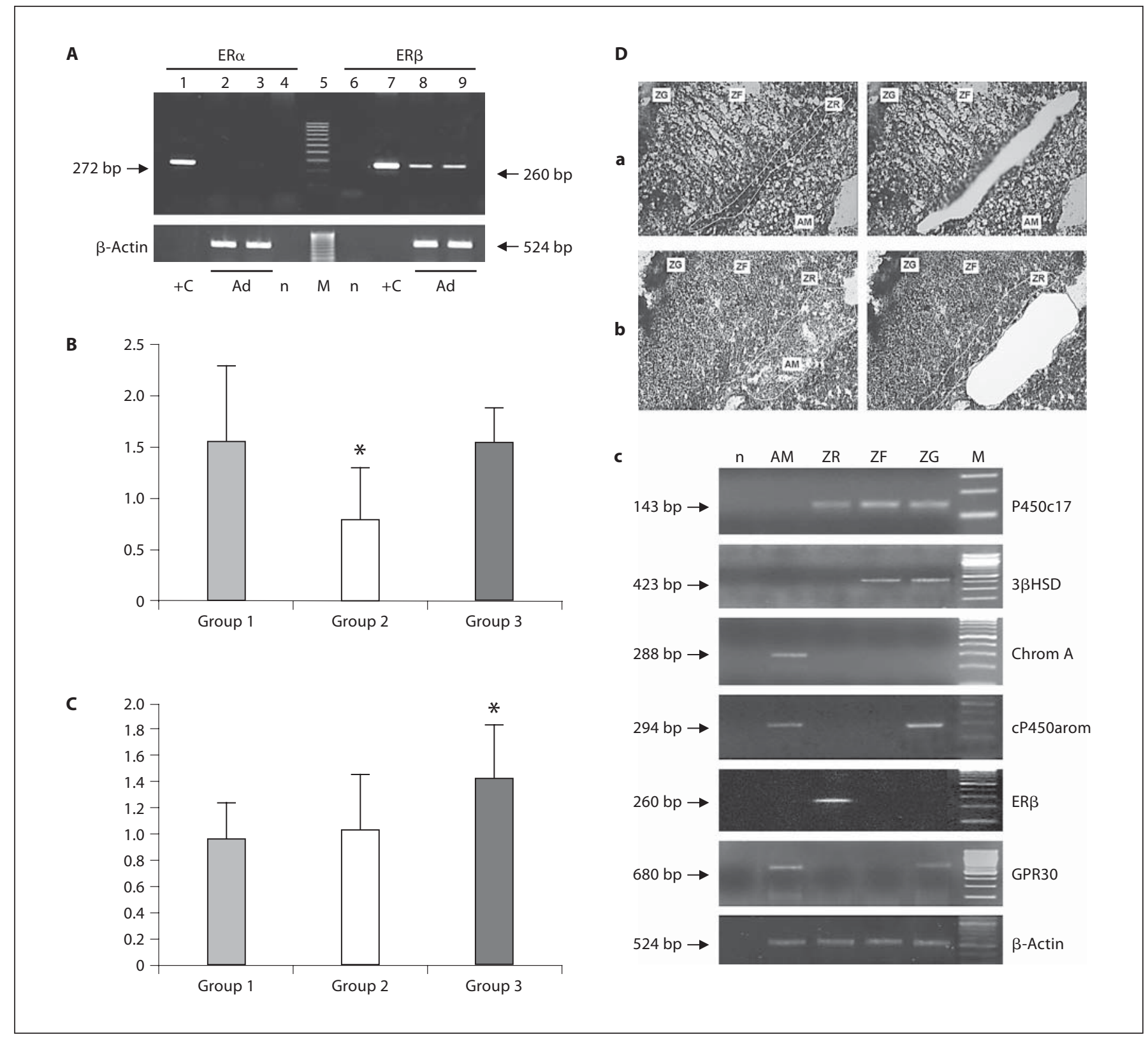

Fig. 4. mRNA expression analysis of $\mathrm{ER} \alpha, \mathrm{ER} \beta, \mathrm{cP} 450$ arom, and GPR30 in normal human adrenal tissues. A RT-PCR analysis of $\mathrm{ER} \alpha$ (lanes 1-4) and ER $\beta$ (lanes 6-9). PCR amplification with primers located at the $\mathrm{N}$ terminal $\mathrm{A} / \mathrm{B}$ region for $\mathrm{ER} \alpha$ and $\mathrm{ER} \beta$ revealed that $\mathrm{ER} \beta$ but not $\mathrm{ER} \alpha$ mRNA was detected in a pool of human prepubertal and postpubertal adrenal glands (Ad). Human ER $\alpha$ and ER $\beta$ clones (lanes 1 and 7, respectively) were used as positive controls $(+\mathrm{C}) . \mathrm{n}=\mathrm{cDNA}$. $\mathrm{M}=100$-bp marker. B, C Semiquantitative RT-PCR analysis of ER $\beta$ and cP450arom, respectively, in normal human adrenal glands of 3 age groups: group $1(\mathrm{n}=12)$, postnatal period of involution of fetal adrenals; group $2(\mathrm{n}=17)$, pre-adrenarche, prepubertal subjects; group 3 $(\mathrm{n}=12)$, post-adrenarche prepubertal and postpubertal subjects. The bars show mean mRNA levels, quantified densitometrically in relation to $\beta$-actin mRNA (AUs); the error bars represent SD in each group. Results are expressed as mean \pm SD. ${ }^{*} \mathrm{p}<0.05$. D Zonal expression of mRNA encoding cP450arom, ER $\beta$ and cP450arom in ZR, ZF, ZG, and adrenal medulla cells of human adrenal tissue from group 3 recovered by laser capture microdissection (LCM). D a, b Representative photomicrographs of an adrenal gland from a 14-year-old before and after LCM of the ZR (D a) and adrenal medulla (D b). D c Total RNA was extracted from cells of the respective zones and analyzed by RT-PCR. Each panel is labeled according to specific primers. ER $\beta$ mRNA was observed primarily in the ZR, while cP450arom and GPR30 in ZG and adrenal medulla. Negative controls (no input cDNA) were run with all reactions (n). M = 100-pb marker. Experiments were reproduced with cDNAs from four adrenal tissues (subjects 15, 16, 21 and 22 years of age). AM = Adrenal medulla [44]. Copyright 2007, The Endocrine Society. 

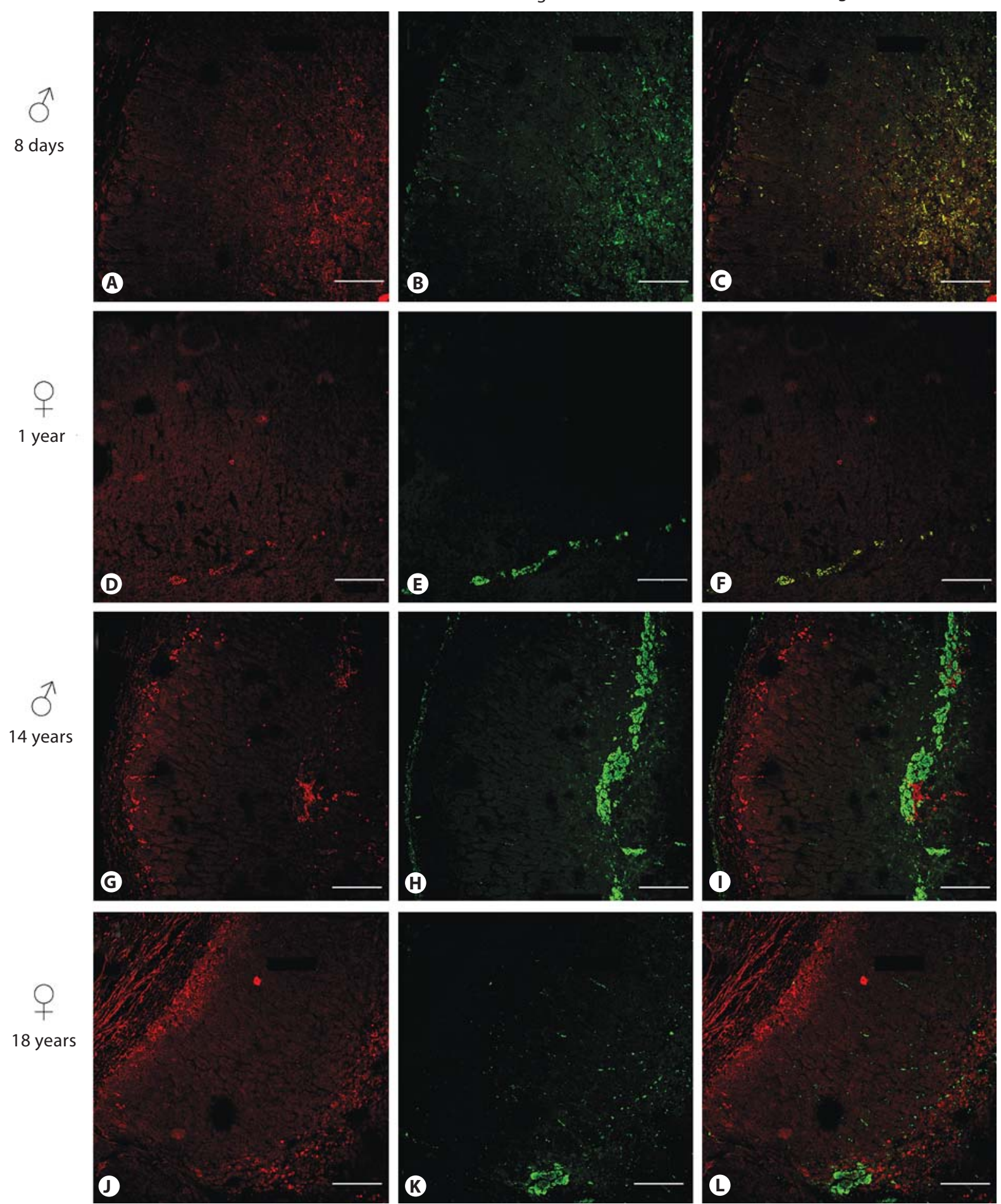

Fig. 5. Laser scanning confocal microscopy of normal adrenal glands of subjects younger than 18 months (A-F) and subjects older than 6 years $(\mathbf{G}-\mathbf{L})$ for cP450arom (red) and chromogranin A (green). cP450arom protein was not expressed in adrenal chromaffin cells of the post-adrenarche group of subjects (older than 6 years; I, L). Immunoreactivities for $\mathrm{cP} 450$ arom and chromo-

granin A (a chromaffin cell marker) were co-localized in adrenal glands from subjects younger than 18 months, as shown in the merged images $\mathbf{C}$ and $\mathbf{F}$. There were no differences in P450arom expression between female and male adrenal glands. Scale bar, $200 \mu \mathrm{m}$ [44]. Copyright 2007, The Endocrine Society. 
and ACTH-stimulated DHEA and DHEA-S production by human fetal adrenal cells in culture [43]. The mechanism of action seems to be a direct inhibition of $3 \beta-H S D 2$ enzyme activity by high estrogen levels [44]. Indeed a recent study described the presence of aromatase expression in prepubertal and pubertal human adrenal glands, as well as the immunolocalization of estrogen receptor $\beta$ in the ZR [45] (fig. 4).

In addition an interaction between the adrenal medulla and adrenal cortex has been proposed [42, 46]. Along this line, it was speculated that $\mathrm{CRH}$ might modulate the communication between chromaffin and ZR cells $[42,47]$. Moreover, in human adrenal tissues, aromatase expression was observed in the adrenal medulla but not in the ZR, suggesting that estrogens produced in the medulla might be involved in the regulation of adrenal androgen production in ZR [45] (fig. 5). Therefore, future progress in characterizing the mechanism of chromaffin-cortical cell interaction might contribute to our knowledge on the mechanisms of adrenarche development and its consequences, particularly in patients with disorders of adrenal androgen production.

The main concepts to retain about the development and functional zonation of the human adrenal gland, the regulators of adrenal androgen production, and their implications for adrenarche, are listed in table 1.

\section{Association of Premature Adrenarche with Risk of Chronic Disease in Adulthood}

Mounting evidence, arising from epidemiological studies, indicates that events occurring in the earliest stages of human development, such as fetal growth restriction, may influence the development of several disorders in adulthood, such as the central distribution of body fat, insulin resistance, the metabolic syndrome, type 2 diabetes, hypertension and ischemic cardiovascular disease [48]. It has been suggested that lower birth weight could result in the reprogramming of a number of metabolic pathways which might have long-term unfavorable consequences on body health. In 1998, Ibañez et al. [49] reported that premature pubarche (and/or exaggerated adrenarche), hyperinsulinism and ovarian hyperandrogenism are associated with low birth weight in girls. This finding linked exaggerated adrenarche with the risk of developing central obesity, hyperinsulinism and polycystic ovary syndrome. Furthermore, adrenal androgen levels were highest in small-for-gestational age infants who gained weigh rapidly during childhood.
Table 1. 'Take-home message' on development and functional zonation of the human adrenal gland

Fetal adrenal: From early in development, the large inner fetal zone is the site of synthesis of large amounts of DHEA and DHEA-S which serve as precursors for estrogen production in the placenta. Definitive zone cells acquire mineralocorticoid synthesis capacity late in gestation. The transitional zone expresses enzymes required for the synthesis of cortisol around mid-gestation. Dispersed chromaffin cells originating from the neural crest migrate through the fetal cortex to colonize the center of the gland. However, the future adrenal medulla is not formed until 12-18 months of age.

The progenitor cell proliferation/migration theory proposes that proliferation of cortical cells takes place in the outermost layers of the adrenal cortex. The theory would be valid for differentiation of the ZG and ZF during fetal life, as well as for the ZR during postnatal life. Hence all cells of the adrenal cortex would have a common origin which becomes functionally differentiated in the appropriate zone environment.

Postnatal adrenal: The fetal zone regresses by the 3rd postnatal month. Before adrenarche, focal islands of ZR cells can be identified, but a fully develop ZR associated with an increment in DHEA and DHEA-S secretion (adrenarche) occurs at 6-8 years of age in both sexes. Specific changes in steroidogenic gene expression include a high 17,20 -lyase activity of P450c17, a low in $3 \beta$-HSD2 expression, and an increase in SULT2A1 for a DHEA sulfotransferase effect. ACTH is necessary but not sufficient to induce adrenarche.

GH-IGF system and insulin as possible modulators of adrenarche: The GH/IGF system and adiposity have been considered major contributors of insulin resistance at puberty. Serum IGF-I levels rise and fall in a pattern similar to serum DHEA-S, and normal puberty is characterized by a state of transient insulin resistance. A significant decrease in insulin sensitivity, as well as a significant negative correlation between serum DHEA-S levels and insulin sensitivity, have been reported in normal late prepuberty girls, and during pubertal development.

Other possible modulators - local estrogen secretion and action, and role of the adrenal medulla: Aromatase expression is observed in the adrenal medulla but not in the ZR suggesting that estrogens produced in the medulla might be involved in the regulation of adrenal androgen production in the ZR.

Charkaluk et al. [50] studied a large population of children with premature pubarche and confirmed that premature pubarche was rare in boys ( $13.4 \%$ of the cohort). They suggested that premature pubarche occurring in children aged less than 2 years is probably different from that occurring in older ones. In agreement with previous reports, 4- to 7.9-year-old girls with premature pubarche tended to be obese and had a higher incidence of intrauterine growth retardation. 
Table 2. 'Take-home message' on the association of premature adrenarche with risk of chronic disease in adulthood

Premature adrenarche in girls has been associated with insulin resistance, hyperinsulinemia, obesity and low birth weight.

High serum IGF-I and low serum IGFBP-1 levels have been reported in girls with premature adrenarche.

Premature adrenarche shares many clinical characteristics with the polycystic ovary syndrome.

Adolescent or adult women who had premature adrenarche might be prone to develop some of the disturbances of the metabolic syndrome.

Indeed, insulin resistance and hyperinsulinemia are common features seen in prepubertal girls with premature adrenarche. In many of these girls, significantly higher ACTH-stimulated $\Delta^{5}$-steroid levels (17-hydroxypregnenolone and DHEA) associated with low SHBG, low IGFBP-1, high IGF-1 levels and an altered lipid profile have been reported [51]. Administration of metformin to girls with premature pubarche appears to prevent the increase in DHEA-S levels [52].

Obesity was more frequently reported in girls with precocious pubarche and the correlation between DHEA$S$ levels and adiposity indexes suggests that overweight might influence the onset of adrenarche [52-55]. Moreover, in normal children, a greater increase in urinary DHEA-S during the period of the greatest rise in BMI was found [56]. These effects might be related to an increase in insulin and leptin levels associated with increased adiposity $[4,57]$. However, in girls with precocious adrenarche, serum leptin levels have been found to be similar [58] or higher [54] than in controls.

On the other hand, the GH-IGF-1 system might modulate adrenal androgens. Indeed, a report by Silfen et al. [53] found that insulin levels in Hispanic girls with premature adrenarche did not differ from that of control girls, but IGF-1 was higher and IGFBP-1 lower in premature adrenarche.

It is then evident that premature adrenarche shares many characteristics with polycystic ovary syndrome, suggesting that they might be different expressions of similar underlying disorders. Therefore, the risk of developing polycystic ovary syndrome at adolescence or soon thereafter in girls with premature adrenarche should alert primary care physicians to follow the evolution of sexual development, age at menarche and menstrual cycles in these girls [59].
On the basis of the evidence discussed above, premature pubarche has to be included among conditions prone to develop central obesity, insulin resistance and its complications for adult life. It is advisable, then, in clinical practice, to be alert to the possible development of these complications in adult life.

The main concepts to remember about the association of premature adrenarche with the risk of chronic diseases in adulthood are listed in table 2.

\section{Final Comments}

Until recently, the secretion of adrenal androgens, as well as the growth of pubic hair in children, was considered as a trivial physiological event, and premature pubarche a minor deviation of normality. However, the numerous recent studies discussed in this review have changed our concept of these events. However, many questions remain, such as: (1) the mechanisms of adrenarche and premature adrenarche; (2) the physiological actions of adrenal androgens, acting as either direct ligands or pro-hormones, and (3) the relationship between the activation of adrenal androgen secretion, growth restriction during fetal life and chronic diseases in adulthood, transforming adrenal androgens in markers of diseases important for human health. Future research might provide responses for a better understanding of these questions. Therefore, improving our knowledge on the mechanisms involved in the regulation of adrenarche is of interest for medical science.

\section{Acknowledgments}

We thank Pablo Ramirez for his expert collaboration on the illustration designs. Supported by grants from Consejo Nacional de Investigaciones Científicas y Técnicas (CONICET) and Fondo para la Investigación Científica y Tecnologica (FONCYT) of Argentina, and from Pfizer Endocrine Care.

References
1 Parker LN: Adrenarche. Endocrinol Metab Clin North Am 1991;20:71-83.

2 Bech K, Tygstrup I, Nerup J: The involution of the foetal adrenal cortex. A light microscopic study. Acta Pathol Microbiol Scand 1969;76:391-400.

3 dePeretti E, Forest MG: Unconjugated dehydroepiandrosterone plasma levels in normal subjects from birth to adolescence in humans: for the use of a sensitive radioimmunoassay. J Clin Endocrinol Metab 1976;43: 982-991. 
\4 Ibáñez L, DiMartino-Nardi J, Potau N, Saenger P: Premature adrenarche. Normal variant or forerunner of adult disease? Endocr Rev 2000;21:671-696.

5 Remer T, Boye KR, Hartmann MF, Wudy SA: Urinary markers of adrenarche: reference values in healthy subjects, aged 3-18 years. J Clin Endocrinol Metab 2005;90:2015-2021.

6 Mesiano S, Jaffe RB: Developmental and functional biology of the primate fetal adrenal cortex. Endocr Rev 1997;18:378-403.

$\checkmark 7$ Keegan CE, Hammer GD: Recent insights into organogenesis of the adrenal cortex. Trends Endocrinol Metab 2002;13:200-208.

>8 Hammer GD, Parker KL, Schimmer BP: Minireview: transcriptional regulation of adrenocortical development. Endocrinology 2005;146:1018-1024.

9 Mesiano S, Coulter CL, Jaffe RB: Localization of cytochrome P450 cholesterol side chain cleavage, cytochrome P450 17 $\alpha$-lyase and $3 \beta$-hydroxysteroid dehydrogenase isomerase steroidogenic enzymes in human and rhesus monkey fetal adrenal glands: reappraisal of functional zonation. J Clin Endocrinol Metab 1993;77:1184-1189.

-10 Spencer SJ, Mesiano S, Lee JY, Jaffe RB: Proliferation and apoptosis in the human adrenal cortex during the fetal and perinatal periods: implications for growth and remodeling. J Clin Endocrinol Metab 1999;84: 1110-1115.

-11 Suzuki T, Sasano H, Takeyama J, Kaneko C, Freije W, Carr R, Rainey WE: Developmental changes in steroidogenic enzymes in human postnatal adrenal cortex: immunohistochemical studies. Clin Endocrinol (Oxf) 2000;53:739-747.

-12 Gell JS, Carr BR, Sasano H, Atkins B, Margraf L, Mason JI, Rainey WE: Adrenarche results from development of a $3 \beta$-hydroxysteroid dehydrogenase-deficient adrenal reticularis. J Clin Endocrinol Metab 1998;83: 3695-3701.

-13 Parker CR Jr, Mixon RL, Brissie RM, Grizzle WE: Aging alters zonation in the adrenal cortex of men. J Clin Endocrinol Metab 1997; 82:3898-3901.

14 Wolkersdorfer G, Bornstein SR: Tissue remodeling in the adrenal gland. Biochem Pharmacol 1998;56:163-171.

15 Miller WL: Molecular biology of steroid hormone synthesis. Endocr Rev 1988;9:295318.

16 Nkajin S, Shively JE, Yuan P, Hall PF: Microsomal cytochrome P-450 from neonatal pig testis: two enzymatic activities $(17 \alpha$-hydroxylase and c17,20-lyase) associated with one protein. Biochemistry 1981;20:4037-4042.

-17 Miller WL, Auchus RJ, Geller DH: The regulation of 17,20 lyase activity. Steroids 1997; 64:133-142.
18 Rhéume E, Lachance Y, Zhao HL, Brenton N, Dumont M, de Launoit Y, Trudel C, Luu-The V, Simard J, Labrie F: Structure and expression of a new complementary DNA encoding the almost exclusive $3 \beta$-hydroxysteroid dehydrogenase $/ \Delta^{4-5}$ isomerase in human adrenals and gonads. Mol Endocrinol 1991;5: 1147-1157.

19 Dardis A, Saraco N, Rivarola MA, Belgorosky A: Decrease in the expression of the $3 \beta$-hydroxysteroid dehydrogenase gene in human adrenal tissue during prepuberty and early puberty. Implications to the mechanism of adrenarche. Pediatr Res 1999;45: 384-388.

20 Bassett MH, Suzuki T, Sasano H, De Vries CJ, Jimenez PT, Carr BR, Rainey WE: The orphan nuclear receptor NGFIB regulates transcription of 3beta-hydroxysteroid dehydrogenase. Implications for the control of adrenal functional zonation. J Biol Chem 2004;279:37622-37630.

21 Goto M, Piper HK, Marcos J, Wood PJ, Wright S, Postle AD, Cameron IT, Mason JI, Wilson DI, Hanley NA: In humans, early cortisol biosynthesis provides a mechanism to safeguard female sexual development. J Clin Invest 2006;116:953-960.

22 Stocco DM, Clark BJ: Regulation of the acute production of steroids in steroidogenic cells. Endocr Rev 1996;17:221-244.

$\checkmark 23$ Weber A, Clark AJ, Perry LA, Honour JW, Savage MO: Diminished adrenal androgen secretion in familial glucocorticoid deficiency implicates a significant role for ACTH in the induction of adrenarche. Clin Endocrinol (Oxf) 1997;46:431-437.

24 Apter D, Pakkerinen A, Hammond GI, Vihko R: Adrenocortical function and puberty, serum ACTH cortisol and dehydroepiandrosterone in girls and boys. Acta Pediatr Scand 1979;69:599-606

-25 L'Allemand D, Penhoat A, Lebrethon MC, Ardevol R, Baehr V, Oelkers W, Saez JM: Insulin-like growth factors enhance steroidogenic enzyme and corticotrophin receptor messenger ribonucleic acid levels and corticotrophin steroidogenic responsiveness in cultured human adrenocortical cells. J Clin Endocrinol Metab 1996;81:3892-3897.

-26 Baquedano MS, Berensztein E, Saraco N, Dorn GV, de Davila MT, Rivarola MA, Belgorosky A: Expression of the IGF system in human adrenal tissues from early infancy to late puberty: implications for the development of adrenarche. Pediatr Res 2005;58: 451-458.

27 Hindmarsh P, Di Silvio L, Pringle PJ, Kurtz $\mathrm{AB}$, Brook CGD: Changes in serum insulin concentration during puberty and their relationship to growth hormone. Clin Endocrinol 1988;21:381-388.

$\checkmark 28$ Amiel SA, Caprio S, Sherwin RS, Plewe G, Haymond MW, Tamborlane WV: Insulin resistance of puberty: a defect restricted to peripheral glucose metabolism. J Clin Endocrinol Metab 1991;72:277-282.
29 Travers SH, Labarta JI, Gargosky SE, Rosenfeld RG, Jeffers BW, Eckel RH: Insulin-like growth factor binding protein-I levels are strongly associated with insulin sensitivity and obesity in early pubertal children. J Clin Endocrinol Metab 1998;83:1935-1939.

-30 Juul A, Bang P, Hertel NT, Main K, Dalgaard P, Jorgensen K, Muller J, Hall K, Skakkebae NS: Serum Insulin-like growth factor-1 in 1,030 healthy children, adolescents and adults: relation to age, sex, stage of puberty, testicular size, and body mass index. J Clin Endocrinol Metab 1994;78:744-752.

31 Caprio S: Insulin the other anabolic hormone of puberty. Acta Paediatr Suppl 1999; 433:84-87.

32 Moran A, Jacobs DR, Steinberger J, Cohen P, Hong C-P, Prineas R, Sinaiko SR: Association between the insulin resistance of puberty and the insulin-like growth factor-1/ growth hormone axis. J Clin Endocrinol Metab 2002;87:4817-4820.

33 Travers SH, Jeffers BW, Bloch CA, Hill JO, Eckel RH: Gender and Tanner stage differences in body composition and insulin sensitivity in early pubertal children. J Clin Endocrinol Metab 1995;80:172-178.

>34 Hoffman RP, Vicini P, Sivitz WI, Cobelli C: Pubertal adolescent male-female differences in insulin sensitivity and glucose effectiveness determined by the one compartment minimal model. Pediatr Res 2000;48:384388 .

35 Guercio G, Rivarola MA, Chaler E, Maceiras M, Belgorosky A: Relationship between the GH/IGF-1, insulin sensitivity, and adrenal androgens in normal prepubertal and pubertal boys. J Clin Endocrinol Metab 2002; 87:1162-1169.

-36 Arslanian SA, Heil BV, Becker DJ, Drash AL: Sexual dimorphism in insulin sensitivity in adolescents with insulin dependent diabetes mellitus. J Clin Endocrinol Metab 1991;72: 920-926.

37 Guercio G, Rivarola MA, Chaler E, Maceiras M, Belgorosky A: Relationship between the GH/IGF-1, insulin sensitivity, and adrenal androgens in normal prepubertal and pubertal girls. J Clin Endocrinol Metab 2003; 88:1389-1393.

38 Denburg MR, Silfen ME, Manibo AM, Chin D, Levine LS, Ferin M, McMahon DJ, Go C, Oberfield SE: Insulin sensitivity and the insulin-like growth factor system in prepubertal boys with premature adrenarche. J Clin Endocrinol Metab 2002;87:5604-5609.

-39 Bloch CA, Clemons P, Sperling MA: Puberty decreases insulin sensitivity. J Pediatr 1987; 110:481-487

40 Caprio S, Plewe G, Diamond MP, Simonson DC, Boulware SD, Sherwin RS, Tamborlane WV: Increased insulin secretion in puberty: a compensatory response to reduction in insulin sensitivity. J Pediatr 1989;114:963967. 
-41 Smith CP, Dunger DB, Williams AJK, Taylor AM, Perry LA, Gale EAM, Preece MA, Savage MO: Relationship between insulin, insulin-like growth factor I, and dehydroepiandrosterone sulfate concentrations during childhood, puberty, and adult life. J Clin Endocrinol Metab 1989;68:932-937.

-42 Ehrhart-Bornstein M, Hinson JP, Bornstein SR, Scherbaum WA, Vinson GP: Intraadrenal interactions in the regulation of adrenocortical steroidogenesis. Endocr Rev 1998; 19:101-143.

43 Mesiano S, Jaffe RB: Interaction of insulinlike growth factor-II and estradiol directs steroidogenesis in the human fetal adrenal towards dehydroepiandrosterone sulfate production. J Clin Endocrinol Metab 1993; 77:754-758.

-44 Gell JS, Oh J, Rainey E, Carr BR: Effect of estradiol on DHEAS production in the human adrenocortical cell line, H295R. J Soc Gynecol Invest 1998;5:144-148.

-45 Baquedano MS, Saraco N, Berensztein E, Pepe C, Bianchini M, Levy E, Goni J, Rivarola MA, Belgorosky A: Identification and developmental changes of aromatase and estrogen receptor expression in prepubertal and pubertal human adrenal tissues. J Clin Endocrinol Metab 2007;92:2215-2222.

-46 Sicard F, Ehrhart-Bornstein M, Corbeil D, Sperber S, Krug AW, Ziegler Ch G, Rettori V, McCann SM, Bornstein SR: Age-dependent regulation of chromaffin cell proliferation by growth factors, dehydroepiandrosterone (DHEA), and DHEA sulfate. Proc Natl Acad Sci USA 2007; 104:2007-2012.

\47 Ibáñez L, Potau N, Marcos MV, de Zegher F: Corticotropin-releasing hormone: a potent androgen secretagogue in girls with hyperandrogenism alter precocious pubarche. J Clin Endocrinol Metab 1999;84:4602-4606.
48 Gillman MW: Developmental origins of health and disease. N Engl J Med 2005;353: 1848-1850.

49 Ibañez L, Potau N, Francois I, de Zegher F: Precocious pubarche, hyperinsulinism, and ovarian hyperandrogensim in girls: relation to reduced fetal growth. J Clin Endocrinol Metab 1998;83:3558-3562.

50 Charkaluk M-L, Trivin C, Brauner R: Premature pubarche as an indicator of how body weight influences the onset of adrenarche. Eur J Pediatr 2004;163:89-93.

51 Vuguin P, Linder B, Rosenfeld RG, Saenger P, DiMartino-Nardi J: The role of insulin sensitivity, insulin-like growth factor I (IGFI) and IGF-binding protein-1 and -3 in the hyperandrogenism of African-American and Caribbean Hispanic girls with premature adrenarche. J Clin Endocrinol Metab 1999;84:2037-2042.

52 Ibañez l, Valls C, Marcos MV, Ong K, Dunger DB, De Zegher F: Insulin sensitization for girls with precocious pubarche and with risk for polycystic ovary syndrome: effects of prepubertal initiation and postpubertal discontinuation of metformin treatment. J Clin Endocrinol Metab 2004;89:4331-4337.

53 Silfen ME, Manibo AM, Ferin M, McMahon DJ, Levine LS, Oberfield SE: Elevated free IGF-1 levels in prepubertal Hispanic girls with premature adrenarche: relationship with hyperandrogenism and insulin sensitivity. J Clin Endocrinol Metab 2002;87:398403.

54 Cizza G, Dorn L, Lotsikas A, Rotenstein D, Chrousos G: Circulating plasma leptin and IGF-1 levels in girls with premature adrenarche: potential implications of a preliminary study. Horm Metab Res 2001;33:138143.
55 Ibañez L, Ong K, de Zegher F, Marcos MV, del Rio L, Dunger DB: Fat distribution in non-obese girls with and without precocious pubarche: central adiposity related to insulinaemia and androgenaemia from prepuberty to postmenarche. Clin Endocr 2003; 58:372-379.

56 Remer T, Manz F: Role of nutritional status in the regulation of adrenarche. J Clin Endocrinol Metab 1999;84:3396-3944.

-57 Biason-Lauber A, Zachmann M, Schoenle EJ: Effect of leptin on CYP17 enzymatic activities in human adrenal cells: new insight in the onset of adrenarche. Endocrinology 2000;141:1446-1454.

58 L'Allemand D, Schmidt S, Rousson V, Brabant G, Gasser T, Grüters A: Associations between body mass, leptin, IGF-1, and circulating adrenal androgens in children with obesity and premature adrenarche. Eur J Endocrinol 2002;146:537-543.

59 Rosenfield RL: Identifying children at risk for polycystic ovary syndrome. J Clin Endocrinol Metab 2007;92:787-796.

60 Belgorosky A, Belgorosky A, Baquedano MS, Guercio G, Rivarola MA: Premature Adrenarche: Harbingers and Consequences; in Pescovitz OH, Walvoord EM (eds): When Puberty Is Precocious. Totowa, Humana Press, 2007, pp 217-245.

61 Dhom G:The prepuberal and puberal growth of the adrenal (adrenarche). Beitr Pathol 1973;150:357-377.

62 Reiter EO, Fuldauer VG, Root AW: Secretion of the adrenal androgen, dehydroepiandrosterone sulfate, during normal infancy, childhood, and adolescence, in sick infants, and in children with endocrinologic abnormalities. J Pediatr 1977;90:766-770. 